\title{
THE FUNCTIONING OF HOSPITAL EMERGENCY ROOMS IN THE ŁÓDŹ REGION IN THE LIGHT OF SPATIAL ANALYSIS
}

\begin{abstract}
The article is devoted to analysis of the matching arrangement and the size of the individual hospital emergency rooms located in the Łódź region to diversify the region's population distribution in terms of municipal level. The data source for the above analysis was the National Action Plan for Emergency Medical System for the Łódź region of 23 June 2015 and Local Data Bank of Central Statistical Office. Analyze takes some variants. Firstly assumes the possibility of getting to the hospital emergency ward by victim's own transport or via emergency medical team. Furthermore taken different time ranges. For your own transport the injured assumed range of 15 and 30 minutes, while for emergency medical team average and maximum intervention time in line with the regional plan. To achieve the objective study used a two-step floating catchment area method in the classic (2SFCA) and enhanced (E2SFCA) form. As a result of the research, it was found that in strategic documents devoted to the organization of medical rescue system on the area of the Łódź province, special attention should be paid to the communes of Bielawy, Zduny, Kiernozia, Chąśno and Kocierzew Południowy in the Łowicz district as well as to the communes of Biała Rawska, Regnów, Sadkowice and Cielądz in the Rawa district and the communes of Przedbórz and Wieruszów. In each adopted research variant, the inhabitants of the aforementioned communes have the lowest accessibility levels to ER.
\end{abstract}

Keywords: emergency department, two-step floating catchment area method, Łódź region, spatial analysis, GIS.

1 Dr Marta Borowska-Stefańska, Instytut Zagospodarowania Środowiska i Polityki Przestrzennej, Wydział Nauk Geograficznych, Uniwersytet Łódzki, ul. Kopcińskiego 31, 90-142 Łódź; e-mail: borosia@op.pl

2 Dr Szymon Wiśniewski, Instytut Zagospodarowania Środowiska i Polityki Przestrzennej, Wydział Nauk Geograficznych, Uniwersytet Łódzki, ul. Kopcińskiego 31, 90-142 Łódź; e-mail: szymon_wisniewski@onet.eu

3 SeniorLecturer PhD Mădălina-Teodora Andrei, Faculty of Engineering, Informatics and Geography, "Spiru Haret" University, Bucharest, Romania, 13 Ion Ghica str., district 3; e-mail: m.andrei.geo@ spiruharet.ro,madalinaa71@yahoo.com 


\section{INTRODUCTION}

The distribution of hospital emergency rooms (ER) is a very important issue due to health safety of inhabitants both on the local and regional level ${ }^{4}$. Spatial differentiation of their accessibility is one of indicators of effectiveness of the health care system at the interface with the transport system of the given area $^{5}$. Research into accessibility of medical services, in this case specialist ones provided by ER, may be conducted on the basis of methods of spatial accessibility analysis ${ }^{6}$. Their results may be used as a diversified diagnostic material for planning investments which focus on health safety of inhabitants or boosting the already existing emergency rooms ${ }^{7}$. Conclusions made on the basis of the analysis may be used to make necessary corrections in relevant strategic documents so that the introduced changes may affect health safety of inhabitants in the most efficient manner possible.

The most important issue in the case of ER is the transport of the injured parties in a sudden health or life-threatening situation to an adequately equipped medical centre in the shortest time possible. The Act on State Medical Rescue as of 8 September 2006 indicates that emergency rooms together with medical rescue teams form two inherent ingredients of this system ${ }^{8}$.

The article is devoted to analysis of adjustment of the distribution and size of individual hospital emergency rooms located in the Łódź province to the differentiation of distribution of the region's population from the perspective of the commune. The source of data for this analysis was the Operating Plan of the State Medical Rescue for the Łódź province as of 23 June 2015 as well as the Local Data Bank of the Main Statistical Office. The research includes 17 emergency rooms characterized by means aggregated number of resuscitation units, intensive care and observation units as well as the number of doctors working in them. The spatial scope of the research is represented by all communes of the Łódź province and those from the neighbourning provinces which are to be found in the isolines of maximum travel time adopted in the research.

The study adopts a number of variants. Firstly, it assumes a possibility of reaching the hospital emergency room with the use of the inured party's own transport (individual car transport) or with assistance of the medical rescue team. Besides different time scopes were adopted. The scope of 15 and 30 minutes was adopted for the inured party's own transport, whereas medical rescue teams were attributed medium and maximum intervention time convergent with the provincial plan in the division between towns of over 10 thousand inhabitants and the remaining areas. In order to achieve the adopted aim of the research the

4 N. Wan, B. Zou, T. Sternberg, A three-step floating catchment area method for analyzing spatial access to health services, "International Journal of Geographical Information Science" 2012, Vol. 26, No. 6.

5 W. Luo, Y. Qi, An enhanced two-step floating catchment area (E2SFCA) method for measuring spatial accessibility to primary care physicians, Health and Place, 2009,15, 4.

6 W. Luo, F. Wang, Measures of spatial accessibility to health care in a GIS environment: synthesis and a case study in the Chicago region, Environment and Planning B: Planning and Design 2003, 30.

7 M. Stępniak, Wykorzystanie metody 2SFCA w badaniach dostęności przestrzennej ustug medycznych, ,Przegląd Geograficzny” 2013, 35, 2.

8 Ustawa z dnia 8 września 2006 r. o Państwowym Ratownictwie Medycznym (tekst jedn. Dz.U. z 2016 r., poz. 1868). 
two-step floating catchment area method (2SFCA) for transport ensured by the medical rescue team and the enhanced two-step floating catchment area method (E2SFCA) with calculations concerning the injured party's own means of transport.

The aim of the article is to assess the adjustment of distribution of hospital emergency rooms located in the Łódź province to the distribution of the region's population. After the introductory part, the study characterizes the system of hospital emergency rooms of the Łódź province. Subsequently, the load of individual emergency rooms and their accessibility levels are analyzed for both the patient's own transport and transport by medical rescue team vehicle. The conclusion part is presented at the end of the article.

\section{HOSPITAL EMERGENCY ROOMS IN THE ŁÓDŹ PROVINCE}

As it was mentioned before, there are 17 hospital emergency rooms within the boundaries of the Łódź province. Three of them are located in Łódź, in Konopnicka Memorial Teaching Hospital No. 4 in Łódź, Copernicus Memorial Hospital in Łódź and III Municipal K. Jonscher Memorial Hospital in Łódź. The remaining hospital emergency rooms can be found in Bełchatów, Brzeziny, Kutno, Łęczyca, Opoczno, Pabianice, Piotrków Trybunalski, Poddębice, Radomsko, Sieradz, Skierniewice, Tomaszów Mazowiecki, Wieluń and Zgierz. The differentiation of the aforementioned hospital emergency rooms in reference to the number of units available is rather inappreciable, ranging from 7 in the case of Poddębice, Skierniewice and Zgierz to 12 in the hospital located in Łódź in Milionowa Street (fig. 1).

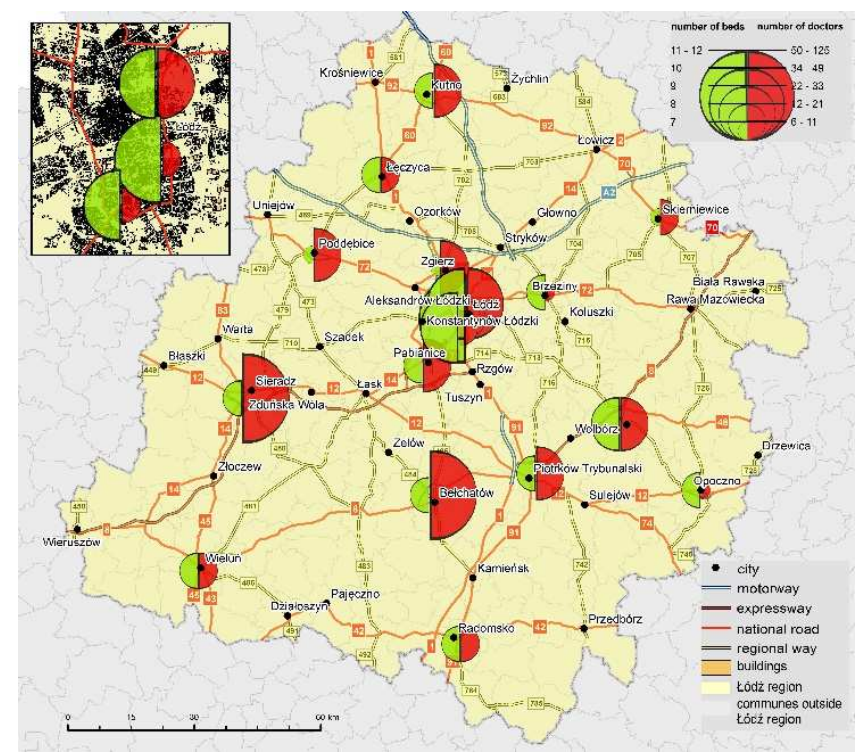

Fig. 1. The number of units and doctors in hospital emergency rooms in the Łódź province in 2015 Source: own elaboration on the basis of the Operating Plan of the State Medical Rescue for the Łódź province as 23 June 2015. 
Far larger differentiation can be observed in the case of the number of all doctors working in emergency rooms in accordance with the provincial plan. The hospital emergency rooms in the hospitals in Bełchatów and Sieradz are markedly the largest. The smallest, in turn, include those in Opoczno, Brzeziny and Skierniewice.

Taking into account that transport of the injured parties to the hospital emergency room takes place by means of car transport, whether it is the patient's own car or that of medical rescue teams, it seems justified to refer the location of hospital emergency rooms to the road infrastructure network of the Łódź province. Due to the radial-concentric layout of the network's main elements, it comes as no surprise that hospital emergency rooms located in hospitals in the centre of the province, namely those in Łódź, Pabianice and Zgierz ${ }^{9}$, are characterized by the highest transport accessibility level. It is also worth stressing the theoretically high transport accessibility of the hospital emergency rooms in, for instance, Kutno, Sieradz and Piotrków Trybunalski. The location in the proximity of a motorway or expressway ensures potentially good transport accessibility. It should be remembered, though, that in order to use the scale of investment to the full the given facility must have access to the node on the given road so that the vehicle transporting the injured may access or exit it. It should be also borne in mind that roads of limited accessibility (motorways and expressways) may, on a local scale, represent a linear barrier ${ }^{10}$.

\section{ACCESSIBILITY AND AVAILABILITY}

Following Taylor ${ }^{11}$, accessibility should be understood as a potential opportunity of using a certain type of transport services by inhabitants of the analyzed area. Accessibility in relation to services provided by hospital emergency rooms is one of fundamental criteria conditioning the feeling of safety among the population ${ }^{12}$ both in urban ${ }^{13}$ and rural areas ${ }^{14}$. While analyzing accessibility to health care services it is also necessary to take into consideration the notion of availability ${ }^{15}$ which, apart from other factors such as the quality of services or cultural and social barriers ${ }^{16}$, is of decisive importance for the effectiveness of

9 S. Wiśniewski, Zróżnicowanie dostępności transportowej miast w województwie łódzkim, Łódź 2015.

${ }^{10} \mathrm{~S}$. Wiśniewski, Zmiany dostępności miast województwa tódzkiego w transporcie indywidualnym w latach 2013-2015, „Przegląd Geograficzny” 2015, 87, 2.

11 Z. Taylor, Dostepność miejsc pracy, nauki i ustug w obszarach wiejskich jako przedmiot badań geografii społeczno-ekonomicznej - próba analizy krytycznej, „Przegląd Geograficzny” 1997, 69, 3-4.

${ }^{12}$ D. Martin, H. Wrigley, S. Barnett, P. Roderick, Increasing the sophistication of access measurement in a rural healthcare study, Health and Place 2002, 8.

13 D. Ley, A Social Geography of City, Harper and Row, London 1983.

${ }^{14}$ D. Martin, H.C.W.L. Williams, 1992, Market-area analysis and accessibility to primary healthcare centres, Environment and Planning A, 1994, 24, 7.

${ }^{15}$ L. Mazurkiewicz, A. Wróbel, Problematyka badawcza geografii medycznej - stan wspótczesny i perspektywy [w:] Przestrzenne problemy zdrowotności, red. L. Mazurkiewicz, A. Wróbel, Warszawa 1990.

16 B.S. Waldorf, S. E. Chen, Spatial models of health outcomes and health behaviours: The role of health care accessibility and availability [w:] Progress in Spatial Analysis. Methods and Applications, red. A. Paez, J. Gallo, R.N. Buliung, S. Dall'erba, Springer-Verlag, Berlin-Heideberg 2010. 
the medical care system. The abovementioned conditionings of medical services accessibility levels were not, however, taken into account in the article. Instead the focus was on accessibility and availability, considering travel time to hospital emergency rooms and the number of units and doctors working in them respectively. Research into spatial accessibility focuses on the relation between places of residence of the population and location of hospital emergency rooms. In contrast, research into availability concentrates on determining whether and to what extent the characteristics of the given hospital emergency room correspond to the needs of potential patients ${ }^{17}$.

Providing the patient with specialized medical aid as quickly as possible is of utmost importance in health and life-threatening situations. It is conditioned, most of all, by travel time to an appropriately equipped ER. In each case it is the ER staff that each time decide about the order of providing aid. If the patient is transported by medical rescue teams, the dispatcher may decide to transport the patient (the injured) to a facility different than the closest one if it cannot admit the patient at the given moment (e.g. due to heavy load) ${ }^{18}$.

In order to avoid the border effect which is artificial in the case of hospital emergency rooms ${ }^{19}$ and at the same time determine to what extent the distribution of hospital emergency rooms corresponds to the real distribution of the population in individual communes it is necessary to determine how the distance between the place of residence and medical facility should be quantified, whether to take into account only those facilities which are the closest to the place of residence or all hospital emergency rooms located within the boundaries of the researched area as well as whether individual facilities should be diversified or not $^{20}$. In this research the aforementioned ambiguities were clarified in the following manner. Each commune included in the analysis is represented by a central point generated for this commune. The research includes all communes located within the boundaries of the Łódź province as well as those from the adjacent provinces whose centroids are covered by 30-minute isochrone of travel time of patients using their own transport to the ER and isochrones of maximum travel time of medical rescue teams for individual 20 operating areas indicated in the provincial plan (it assumes the values ranging from 15 minutes to cities with more than 10 thousand inhabitants in the area no. 10/07 to 169 minutes for the area no. 10/01). This allows to make research results real as it is assumed that the injured from beyond the Łódź province may also be accessed/admitted by Łódź province hospital emergency rooms. The distance, expressed in units of travel time, between each analyzed ER and individual communes was specified under the assumption that travel speed of the patient using his or her own transport is solely affected by traffic regulations. All other factors, such as weather conditions or congestion, were excluded from the research. In this way gross travel time was established ${ }^{21}$. It was arbitrarily assumed that the speed of medical

${ }^{17}$ L. Wyszewianski, Access to care: Remembering old lessons, "Health Services Research" 2002, 37, 6.

${ }^{18}$ M. Stępniak, Wykorzystanie metody 2SFCA w badaniach dostępności przestrzennej ustug medycznych, ,Przegląd Geograficzny” 2013, 35, 2.

${ }_{19}$ M.F. Guagliardo, Spatial accessibility of primary care: concepts, methods and challenges, "International Journal of Health Geographics" 2004, 3, 3.

${ }^{20}$ M. Stępniak, Wykorzystanie metody 2SFCA w badaniach dostęności przestrzennej ustug medycznych, ,Przegląd Geograficzny” 2013, 35, 2.

${ }^{21} \mathrm{~S}$. Wiśniewski, Regionalna dostępność transportowa w odniesieniu do samochodowego transportu indywidualnego. Studium przypadku dla Łodzi i Wieruszowa, „Przegląd Komunikacyjny” 2015, nr 5. 
rescue team vehicles is $20 \mathrm{~km} / \mathrm{h}$ higher than it is allowed by travel regulations on the given road section.

\section{SPATIAL DIFFERENTIATION OF ACCESSIBILITY TO HOSPITAL EMERGENCY ROOMS: THE PATIENT'S OWN TRANSPORT}

The research into spatial accessibility of hospital emergency rooms in the Łódź province focuses on the connections between the distribution of the population and location of the services in question. Research into availability focuses, in turn, on determining the level on which the supply of services provided by hospital emergency rooms corresponds to theoretical needs of Łódź province inhabitants. Taking both dimensions into account allows to analyze accessibility in the most comprehensive way. This solution also allows to avoid interpretation errors which accompany analyses based on determining figures attributable to one inhabitant of the given area since this kind of research lacks its spatial dimension as a result, for instance, of not including the aforementioned border effect or inability to determine the relation between the distribution of hospital emergency rooms and the distribution of the population in individual primary fields of the analysis ${ }^{22}$. The use of the two-step floating catchment area method allows to avoid limitations of this sort.

Two stages connected with the adopted research method were singled out in the analysis of spatial differentiation of accessibility to hospital emergency rooms in the Łódź province with the assumption of using the injured party's own transport. The standard version of the two-step floating catchment area method (2SFCA) formed basis for the introduction of its enhanced version $(\mathrm{E} 2 \mathrm{SFCA})^{23}$. This version introduces to the original method weights which allow to differentiate individual scopes of travel time to hospital emergency rooms. Hence the model is based on a more rational assumption of demand for medical services. This weight is subsequently used to calculate the needs of individual commune populations for medical services, eliminating frequently occurring overestimations.

The first part of the method consists in determining the impact area of every hospital emergency room, adopting the border travel time: this research adopts two variants, namely 15 and 30-minute travel time when the injured organizes his or her own transport. The isochrone of theoretical travel time was drawn for each hospital emergency room. Each time the travel time between the ER and central point of each analyzed commune was determined, assuming that the journey takes place on the route ensuring the shortest travel time possible. Then all hospital emergency rooms were found for both delineated zones $D\left(D_{1}-\right.$ 15 minute zone and $D_{2}-30$ minute zone) and each of them was given weights in accordance with the exponential function.

\footnotetext{
${ }^{22}$ A. Geronimus, J. Bound, L. Neidert, On the validity of using census geocode characteristics to proxy individual socioeconomic characteristics, "Journal of the American Statistical Association" 1996, 91, 434.

${ }^{23}$ P.W. Gething, F.A. Johnson, F. Frempong-Ainguah, P. Nyarko, A. Baschieri, P. Aboagye, J. Falkingham, Z. Matthews, P. M. Atkinson, Geographical access to care at birth in Ghana: a barrier to safe motherhood, BMC Public Health 2012.
} 
The main issue determining the results of accessibility models is the function of space resistance used ${ }^{24}$. Originally, the E2SFCA method proposed by Luo and $\mathrm{Qi}^{25}$ used the normal (Gaussian) distribution yet in this research it was decided to use instead the exponential function, which is most frequently used in empirical research, of the base equal $e$, i.e. that of the natural algorithm. The formula for the exponential function of space resistance in research into accessibility assumes the following form:

$$
f_{d d}=\exp \left(-\beta t_{i j}\right)
$$

where:

$f_{d d}$ - space resistance function,

$t_{i j}$ - travel time between commune $i$ and hospital $j$,

$\beta$ - beta parameter.

The value of the bata parameter was taken from Rosik's research $(2012)^{26}$ devoted to land accessibility of Poland. It was calculated there on the basis of average travel distances depending on travel motivation. It was assumed that the bata parameter was determined in such a way that the attractiveness of the destination was about $1 / 2$ for individual travel motivations with the average travel distance. Travel to hospital emergency rooms was qualified as short travel and in accordance with the research quoted the beta parameter equaling 0.0154 was used in the space resistance function.

The individual indicator $T R_{j}$ is calculated for every out of 17 hospital emergency rooms and it represents its weight per the aggregated number of the inhabitants (potential patients) living in communes localized by the area delineated by the given isochrone:

$$
\mathrm{TR}_{\mathrm{j}}=\frac{s_{j}}{\sum_{k \epsilon\left\{d_{k j} \epsilon D_{r}\right\}} P_{k} W_{r}}
$$

where:

$S_{j}$ - weight (number of units/number of doctors) of hospital emergency room $j$;

$W_{r}$ - weight in accordance with the exponential function suitable for individual zones $\left(D_{1}\right.$ and $D_{2}$ ),

$P_{k}$ - size of population $k$ of commune $i$ being within the scope of the research, $d_{k j}$ - travel time between a hospital emergency room $j$ and commune $i$ of population $k$, $D_{r}$ - subsequent zones of accessibility analysis (15-minute and 30-minute).

In the second part of the analysis the attention shifts to the communes where potential patients live. An area is delineated for every commune as in the first stage of the analysis, using the adopted border value of travel time to hospitals. Then for every commune accessibility indicator $T A_{i}^{F}$ is calculated which is the sum of products of value $T R_{j}$ obtained for individual hospital emergency rooms and weights $W_{r}$ on the area of the individual area of commune $i$ :

\footnotetext{
${ }^{24}$ P. Rosik, Dostępność lądowa przestrzeni Polski w wymiarze europejskim, „Prace Geograficzne” nr 233, 2012.

25 W. Luo, Y. Qi, 2009, An enhanced two-step floating catchment area (E2SFCA) method for measuring spatial accessibility to primary care physicians, Health and Place" 2009, $15,4$.

${ }^{26}$ P. Rosik, Dostępność lądowa...
} 


$$
T A_{i}^{F}=\sum_{j \epsilon\left\{d_{i j} \in D_{r}\right\}} R_{j} W_{r}
$$

One unquestionable advantage of E2SFCA as compared to its standard variant is that it goes beyond the solely dichtomic character of differentiating individual weights for the analysis zones. Originally, the method gives weight equal to 1 to individual locations within the research scope whereas locations outside the analysis are attributed weight 0 , thus excluding them from the research. The enhanced method provides a solution to this problem, differentiating also individual locations within the given research zone, making the model more in line with real conditions. It is a method based on the gravity model and at the same time it refers to the reality where in real conditions the potential injured are not bothered by a few minutes difference in travel time to the hospital emergency room. This makes the results of E2SFCA methods easy to interpret and use as they express the relation of hospital emergency rooms to the population in a comprehensible manner. Due to progress in GIS technology and availability of vector data for the road network, the E2SFCA method may be easily implemented to all kinds of studies bordering on individual elements of development and transport network ${ }^{27}$.

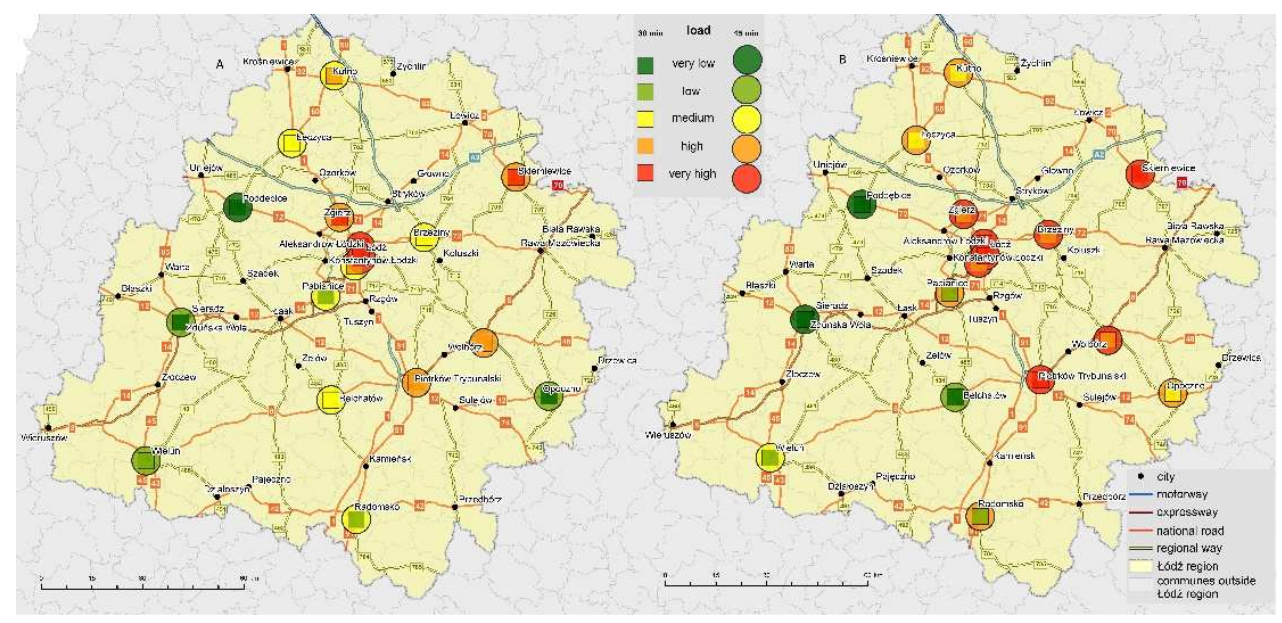

Fig. 2. Potential load of hospital emergency rooms in the Łódź province in 2015 with regard to the number of units (A) and the number of doctors (B) under the assumption of 15 and 30-minute maximum travel time patients suing their own transport

Source: own study.

In the first place the consequences of theoretical load of hospital emergency rooms will be subject to analysis (fig. 2). Assuming the maximum travel time of the patient amounting to 15 minutes and taking into account the number of units available for the injured, it may be concluded that two Łódź hospital emergency rooms have the greatest load. Moreover,

${ }^{27}$ N. Schuurman, M. Bérubé, V.A. Crooks, Measuring potential spatial access to primary health care physicians using a modified gravity model, Canadian Geographer/Le Géographe Canadien, 2010, 54. 
hospital emergency rooms in Zgierz, Piotrków Trybunalski, Wolborz and Skierniewice are characterized by values above par, which manifests a high level of transport accessibility of these towns. The location near the most important roads offers a potential opportunity to reach the emergency room quickly. Emergency rooms in the region's western part are characterized, in turn, by the lowest load. Extending the maximum theoretical travel time of the patient to 30 minutes does not bring about any appreciable changes in the load of ER. They manifest themselves, however, in the analysis of the number of doctors working in ER. Regardless of the maximum travel time, the highest load of ER can be found in in the central and eastern part of the region. In this way the analyzed ER availability is also characterized by higher spatial differentiation of ER load, which results directly from larger differences in the number of doctors working in individual hospital emergency rooms.

Using the load calculated for every ER, it was possible to point to spatial differentiation of accessibility to them for Łódź province inhabitants. Taking into account the number of units in ER and the assumption of shorter maximum travel time, it is only the inhabitants of the communes on the area of which the given ER is located that have accessibility to specialist medical care on average and above average level. Changing the maximum travel time to 30 minutes results in considerable spatial differentiation of accessibility levels. The highest accessibility levels may be found, most of all, in the communes of the district and occasional units from the neighbouring districts. It is worth noting a group of communes located along the western section of the S8 expressway of accessibility levels above the average. Particularly unfavourable situation concerns the communes situated along the north-eastern border of the Łódź region (in particular the districts of Rawa, Łowicz and Skierniewice). In the case when the accessibility of ER is determined by number of specialist working in it,

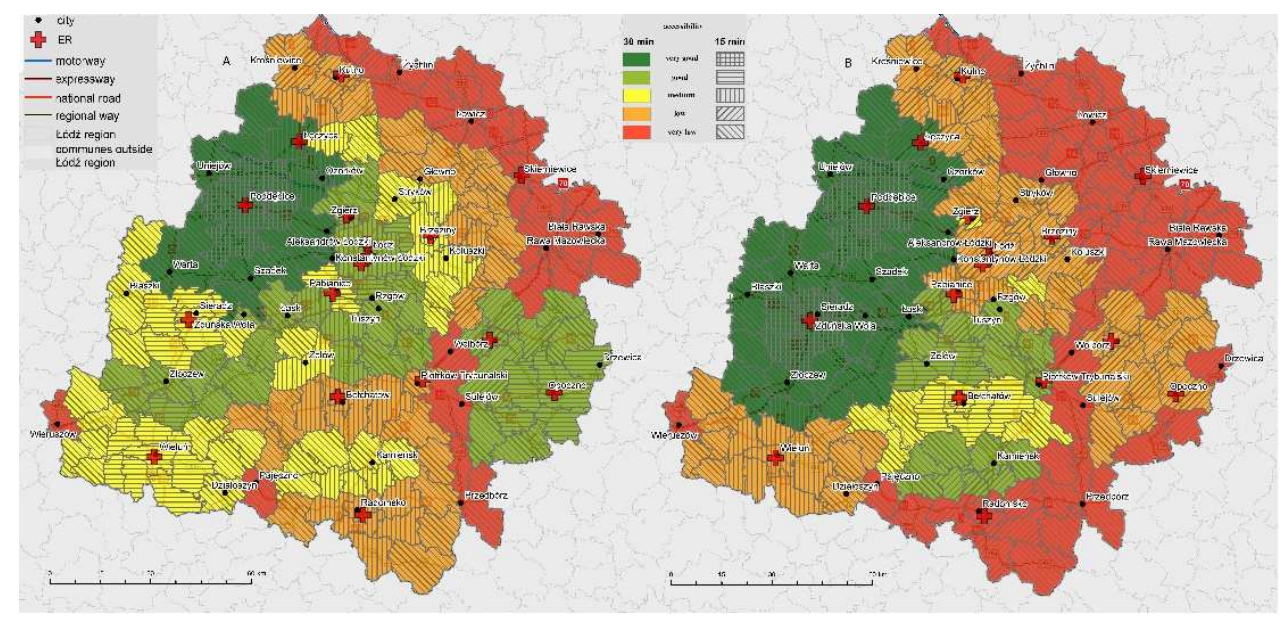

Fig. 3. Spatial differentiation of accessibility to hospital emergency rooms in the Łódź province in 2015 with regard to the number of units (A) and the number of doctors (B) with the assumption of 15 and 30-minute maximum travel time of patients suing their own transport

Source: own study. 
there is a clear decrease in the spatial differentiation of accessibility with the maximum 30-minute transport. There is a rise, above all, in areas of the most and the least favourable situation which are rather homogenous as far as accessibility levels are concerned. The area characterized by best accessibility extended in the southern direction, including, most of all, the districts of Sieradz and Zduńska Wola and partly the Łask district. The area of lowest accessibility spread, in turn, in the direction of the region's centre and included communes in its southern part, mainly communes of the Radomsko district. There was also a clear decrease in the number of communes of medium accessibility levels as well as those of slightly lower level, although at the same time these conditionings also include communes in the centre of the province, including Łódź (fig. 3).

\section{SPATIAL DIFFERENTIATION OF ACCESSIBILITY TO ER: TRANSPORT PROVIDED BY MEDICAL RESCUE TEAMS}

Space resistance seems to be of lesser importance if transport is provided by medical rescue teams. The medical rescue team in an emergency vehicle does not take any subjective decision where to transport the injured. The decision is a product of a certain number of factors and is taken with possibly full information on state of the injured as well as accessibility and availability of individual hospital emergency rooms. When the injured uses his or her own means of transport to hospital, he or she does not have access to any of the abovementioned data as the patient is not capable of assessing accurately how serious his or her condition is, what road conditions he or she will face or whether the load of the selected ER is so high that it will be necessary to wait for suitable assistance.

This is why the standard two-step floating catchment area method was employed in order to determine spatial differentiation of accessibility to ER with the assumption of transport provided by medical rescue teams ${ }^{28}$. Spatial accessibility determined by this method takes into account both the factors of supply and demand. This method was first used for analysis of spatial accessibility of the labour market in the US ${ }^{29}$. In this scope the method was also used in reference to the Mazovia province by Komornicki and others ${ }^{30}$. The first part of the standard two-step floating catchment area method is based on determining the operation area of every ER, assuming the border value of travel time: in this variant it is the average and maximum travel time of the medical rescue team for individual 20 operating areas delineated in the provincial plan in the division into towns with over 10 thousand inhabitants and the remaining areas. Then an individual indicator $K R_{j}$ is calculated for every ER and it represents the number of units or doctors in the given facility per aggregated number of inhabitants (potential patients) who live in the communes located on the area delineated by the given isochrone:

${ }^{28}$ D.P. Albert, F.B. Butar, Estimating the de-designation of single-county HPSAs in the United States by counting naturopathic physicians as medical doctors. Applied Geography” 2005, 25.

M. Langford, G. Higgs, Measuring potential access to primary healthcare services: the influence of alternative spatial representations of population, The Professional Geographer" 2006, 58 (3).

F. Cervigni, Y. Suzuki, T. Ishii, A. Hata, Spatial accessibility to pediatric services, "Journal of Community Health" 2008, 33.

29 Z.-R. Peng, The jobs-housing balance and urban commuting, Urban Studies, 1997, 34, 8.

${ }^{30}$ T. Komornicki, R. Wiśniewski, M. Stępniak, P. Siłka, P. Rosik, Rynek pracy w województwie mazowieckim, Mazowsze. Studia Regionalne, 2013, 12. 


$$
\mathrm{KR}_{\mathrm{j}}=\frac{s_{j}}{\sum_{i \epsilon\left\{d_{i j} \leq d_{\max } P_{i}\right.}}
$$

where:

$S_{j}$ - weight (number of units/number of doctors) of hospital emergency room $j$,

$P_{i}$ - number of the population of commune $i$;

$d_{i j}$ - travel time between hospital emergency room $j$ and commune $i$,

$d_{\max }$ - isochrone delineating average or maximum travel time of the medical rescue team to ER.

In this way the potential load of ER is calculated.

In the second part of the standard two-step floating catchment area method the attention shifts to the communes populated by the potential injured. An area is delineated for every centroid of the commune, as in the first stage of the analysis, by means of the adopted border value of medical rescue team travel time. Subsequently, the accessibility indicator $K A$ is calculated for every commune $i$ included in the research and it represents a sum of values $K R_{j}$ obtained for all emergency rooms located on the area of the individual area of commune $i$ :

$$
\mathrm{KA}_{\mathrm{i}}=\sum_{j \in\left\{d_{i j} \leq d_{\max }\right\}} K R_{j}
$$

When the patient is transported by medical rescue teams the load of individual emergency rooms is higher in absolute terms than it is in the case of the injured party's own transport irrespective of the adopted maximum distance and weight of ER. This is a natural consequence of a clearly higher travel speed of the emergency vehicle despite high differentiation of travel time of medical rescue teams in different regions. Hospital emergency rooms in Łódź have by far the greatest theoretical number of patients either in the situation when ER accessibility is determined by the number of units or by the number of doctors (fig. 4).

Spatial differentiation of accessibility to emergency rooms when the injured is transported by the medical rescue team (irrespective of the adopted maximum travel time and the weight of the emergency room) is markedly higher than in the case of the patient's individual transport.

The variant of the research adopting ER accessibility in the form of the number of units and the rescue team's travel time not exceeding the average for the given region shows that the inhabitants of the commune and town of Brzeziny as well as those of Poddębice have the highest accessibility to ER. Only those communes within whose boundaries there is a hospital emergency room have above average and average results with the aforementioned conditionings. The opposite situation may be encountered with the assumption that the medical rescue team vehicle reaches ER with the injured in the maximum time for the given region. There are clear areas of high accessibility comprising a few communes located between emergency rooms, such as those between the emergency rooms in Poddębice and Łęczyca, Łęczyca and Kutno or Bełchatów and Piotrków. The highest accessibility levels may be found in a complex of communes on the border of the district of Tomaszów, Opoczno and Piotrków which remain within the impact of emergency rooms in Piotrków Trybunalski, Wolborz and Opoczno. Problem areas of very low accessibility levels are a kind of buffer zones of areas of functioning of individual emergency rooms. Since in both 
time variants and irrespective of the adopted weight of ER these are the same communes, it seems justified that their situation should be analyzed further.

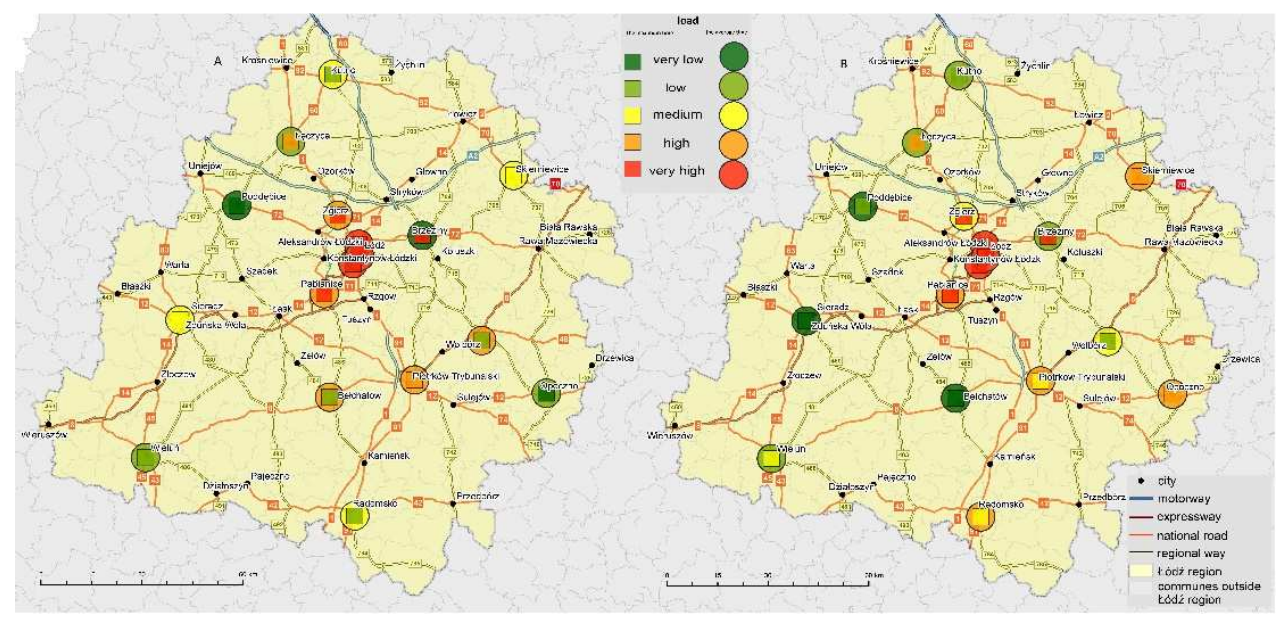

Fig. 4. Potential load of hospital emergency rooms in the Łódź province in 2015 in relation to the number of units (A) and numbers of doctors (B) with the assumption of average and maximum time of transport of patients by medical rescue teams

Source: own study.

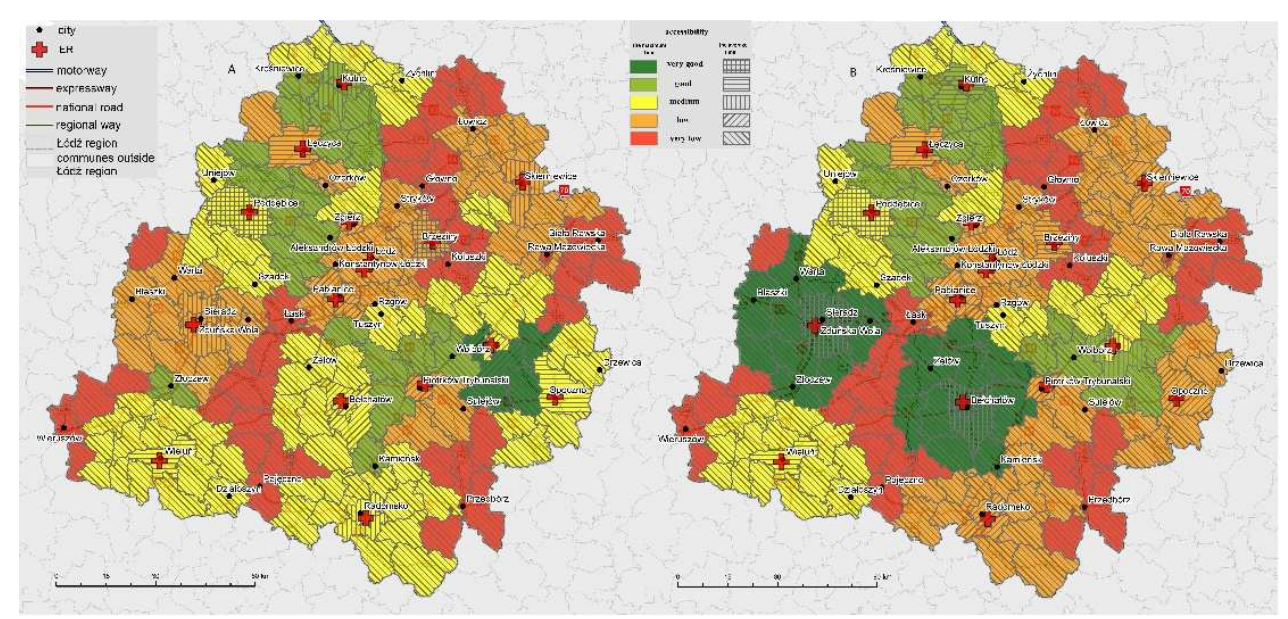

Fig. 5. Spatial differentiation of accessibility to hospital emergency rooms in the Łódź province in 2015 in relation to the number of units (A) and numbers of doctors (B) with the assumption of average and maximum time of transport of patients by medical rescue teams

Source: own study.

Putting ER accessibility in the form of the number of doctors hardly brings any changes to the distribution of areas of individual accessibility levels to areas (fig. 5). The increase in 
accessibility for the district of Sieradz and Zduńska Wola is the most visible and it results from the markedly biggest number of staff working in emergency rooms in the capitals of these districts.

\section{CONCLUSIONS}

Accomplishing the aim of the article concerning the assessment of adjustment of ER distribution in the Łódź province to the distribution of the region's population allows to define areas in relation to which it is necessary to conduct a thorough analysis due to their particularly unfavourable situation. In strategic documents devoted to the organization of medical rescue system on the area of the Łódź province, special attention should be paid to the communes of Bielawy, Zduny, Kiernozia, Chąśno and Kocierzew Południowy in the Łowicz district as well as to the communes of Biała Rawska, Regnów, Sadkowice and Cielądz in the Rawa district and the communes of Przedbórz and Wieruszów. In each adopted research variant, the inhabitants of the aforementioned communes have the lowest accessibility levels to ER. Assuming that the analysis concerns solely emergency rooms within the boundaries of the Łódź province, it seems necessary to increase the effectiveness of the system on these areas through, for instance, densification of emergency wards, increasing their accessibility or increasing the level of accessibility of the already existing emergency rooms, which seems particularly difficult. Bearing in mind that emergency rooms from the adjacent provinces join in servicing the problematic areas, it is vital to cater for appropriate coordination of individual facilities so as to minimize the existing accessibility deficits.

\section{REFERENCES}

[1] Albert D.P., Butar F.B., Estimating the de-designation of single-county HPSAs in the United States by counting naturopathic physicians as medical doctors, "Applied Geography" 2005, 25.

[2] Cervigni F., Suzuki Y., Ishii T., Hata A., Spatial accessibility to pediatric services, "Journal of Community Health" 2008, 33.

[3] Geronimus A., Bound J., Neidert L., On the validity of using census geocode characteristics to proxy individual socioeconomic characteristics, "Journal of the American Statistical Association" 1996, 91, 434.

[4] Gething P.W., Johnson F.A., Frempong-Ainguah F., Nyarko P., Baschieri A., Aboagye P., Falkingham J., Matthews Z., Atkinson P.M., Geographical access to care at birth in Ghana: a barrier to safe motherhood, BMC Public Health 2012, 12:991.

[5] Guagliardo M.F., Spatial accessibility of primary care: concepts, methods and challenges, "International Journal of Health Geographics" 2004, 3, 3.

[6] Komornicki T., Wiśniewski R., Stępniak M., Siłka P., Rosik P., Rynek pracy w województwie mazowieckim, „Mazowsze. Studia Regionalne” 2013, 12.

[7] Langford M., Higgs G., Measuring potential access to primary healthcare services: the influence of alternative spatial representations of population, "The Professional Geographer" 2006, 58 (3).

[8] Ley D., A Social Geography of City, Harper and Row, London 1983.

[9] Luo W., Qi Y., An enhanced two-step floating catchment area (E2SFCA) method for measuring spatial accessibility to primary care physicians, "Health and Place" 2009, 15, 4. 
[10] Luo W., Wang F., Measures of spatial accessibility to health care in a GIS environment: synthesis and a case study in the Chicago region, Environment and Planning B: Planning and Design, 2003, 30.

[11] Martin D., Williams H.C.W.L., Market-area analysis and accessibility to primary healthcare centres, Environment and Planning A, 1992, 24, 7.

[12] Martin D., Wrigley H., Barnett S., Roderick P., Increasing the sophistication of access measurement in a rural healthcare study, Health and Place, 2002, 8.

[13] Mazurkiewicz L., Wróbel A., Problematyka badawcza geografii medycznej - stan wspótczesny i perspektywy [w:] Przestrzenne problemy zdrowotności, red. L. Mazurkiewicz, A. Wróbel, IGiPZ PAN, Conference Papers, 9, Warszawa 1990.

[14] Peng Z.-R., The jobs-housing balance and urban commuting, Urban Studies, 1997, $34,8$.

[15] Rosik P., Dostępność lądowa przestrzeni Polski w wymiarze europejskim, Prace Geograficzne nr 233, IGiPZ PAN 2012.

[16] Schuurman N., Bérubé M., Crooks V.A., Measuring potential spatial access to primary health care physicians using a modified gravity model, Canadian Geographer/Le Géographe Canadien, 2010, 54.

[17] Stępniak M., Wykorzystanie metody 2SFCA w badaniach dostępności przestrzennej usług medycznych, ,Przegląd Geograficzny” 2013, 35, 2.

[18] Taylor Z., Dostepność miejsc pracy, nauki i ustug w obszarach wiejskich jako przedmiot badań geografii społeczno-ekonomicznej - próba analizy krytycznej, „Przegląd Geograficzny" 1997, 69, 3-4.

[19] Waldorf B.S., Chen S.E., Spatial models of health outcomes and health behaviours: The role of health care accessibility and availability [w:] Progress in Spatial Analysis. Methods and Applications, red. A. Paez, J. Gallo, R.N. Buliung, S. Dall'erba, Springer-Verlag, BerlinHeideberg 2010.

[20] Wyszewianski L., Access to care: Remembering old lessons, "Health Services Research" 2002, 37, 6 .

[21] Ustawa z dnia 8 września 2006 r. o Państwowym Ratownictwie Medycznym (tekst jedn. Dz.U. z 2016 r., poz. 1868).

[22] Wan N., Zou B., Sternberg T., A three-step floating catchment area method for analyzing spatial access to health services, "International Journal of Geographical Information Science" 2012, Vol. 26, No. 6, June 2012.

[23] Wiśniewski S., Regionalna dostęność transportowa $w$ odniesieniu do samochodowego transportu indywidualnego. Studium przypadku dla Łodzi i Wieruszowa, „Przegląd Komunikacyjny" 2015, nr 5.

[24] Wiśniewski S., Zróżnicowanie dostępności transportowej miast $w$ województwie tódzkim, Wydawnictwo Uniwersytetu Łódzkiego, Łódź 2015.

[25] Wiśniewski S., Zmiany dostępności miast województwa tódzkiego $w$ transporcie indywidualnym w latach 2013-2015, „Przegląd Geograficzny” 2015, 87, 2.

\section{DZIAŁALNOŚĆ SZPITALNYCH ODDZIAŁÓW RATUNKOWYCH WOJEWÓDZTWA ŁÓDZKIEGO W UJĘCIU PRZESTRZENNYM}

Prezentowany artykuł poświęcony jest analizie dopasowania rozmieszczenia i wielkości poszczególnych szpitalnych oddziałów ratunkowych zlokalizowanych w województwie łódzkim do zróżnicowania rozmieszczenia ludności regionu w ujęciu gminnym. Źródłem danych 
do powyższej analizy był Plan działania systemu Państwowe Ratownictwo Medyczne dla województwa łódzkiego z 23 czerwca 2015 r. oraz Bank Danych Lokalnych Głównego Urzędu Statystycznego. Opracowanie przyjmuje kilka wariantów. Po pierwsze, zakłada możliwość dotarcia do szpitalnego oddziału ratunkowego własnym transportem poszkodowanego lub za pośrednictwem zespołu ratownictwa medycznego (ZRM). Ponadto przyjęto różne zakresy czasowe. Dla własnego transportu poszkodowanego założono zakres 15 i 30 minut dojazdu, zaś dla ZRM średni i maksymalny czas interwencji zgodny z planem wojewódzkim. Dla osiągnięcia założonego celu badania zastosowano dwuetapową metodę określania obszarów rynkowych w wariacie klasycznym (2SFCA) oraz wzmocnionym (E2SFCA). W wyniku przeprowadzonych badań stwierdzono, że w dokumentach strategicznych poświęconych organizacji systemu ratownictwa medycznego na terenie województwa łódzkiego należy zwrócić szczególną uwagę na gminy Bielawy, Zduny, Kiernozia, Chąśno i Kocierzew Południowy w powiecie łowickim oraz gminy Biała Rawska, Regnów, Sadkowice i Cielądz w powiecie rawskim oraz gminy Przedbórz i Wieruszów. W każdym przyjętym wariancie badawczym mieszkańcy wyżej wspomnianych gmin mają najniższy poziom dostępności do szpitalnych oddziałów ratunkowych. Zakładając, że analiza dotyczy wyłącznie oddziałów ratunkowych w granicach województwa łódzkiego, konieczne wydaje się zwiększenie efektywności systemu w tych obszarach np. poprzez ich zagęszczenie lub zwiększenie ich dostępności.

Słowa kluczowe: szpitalny oddział ratunkowy, dwuetapowa metoda określania obszarów rynkowych, województwo łódzkie, analizy przestrzenne, GIS.

\section{DOI: 10.7862/rz.2017.mmr.14}

Tekst złożono w redakcji: kwiecień 2017 r.

Przyjęto do druku: czerwiec 2017 r. 
